\title{
Effect of temperature shifts and anammox biomass immobilization on sequencing batch reactor performance and bacterial genes abundance
}

\author{
A. Banach-Wiśniewska ${ }^{1}$ (D) M. Ćwiertniewicz-Wojciechowska' $\cdot$ A. Ziembińska-Buczyńska ${ }^{1}$
}

Received: 15 July 2020 / Revised: 9 September 2020 / Accepted: 23 September 2020 / Published online: 10 October 2020

(c) The Author(s) 2020

\begin{abstract}
Implementation of anaerobic ammonium oxidation (anammox) below its optimal temperature, known as "cold anammox", may lead to its common use in wastewater treatment plants, reducing the operational costs of wastewater treatment. Thus, we investigated the effects of immobilization in polyvinyl alcohol-sodium alginate gel beads on anammox performance at temperatures of $30^{\circ} \mathrm{C}, 23{ }^{\circ} \mathrm{C}$, and $15^{\circ} \mathrm{C}$ in laboratory-scale sequencing batch reactors. We determined the relative gene abundance of the nitrogen removal bacterial groups, which are considered as the key functional microbes of nitrogen cycle in activated sludge: denitrifies, ammonia-oxidizing bacteria, nitrite-oxidizing bacteria, and anammox bacteria. Nitrogen removal efficiency was higher for immobilized anammox sludge in comparison with non-immobilized anammox biomass at each investigated temperature. At $30^{\circ} \mathrm{C}$, nitrogen removal efficiency was $83.7 \pm 6.46 \%$ for immobilized reactor, and $79.4 \pm 7.83 \%$ for the control reactor, while at $15{ }^{\circ} \mathrm{C}$ was remained at the level of $50 \pm 2.5 \%$ for immobilized reactor, and fluctuated from 13.2 to $45.3 \%$ for the control one. During temperature shifts, the process was also more stable in the case of the reactor with immobilized biomass. A statistically significant correlation was found between nitrogen removal efficiency and hydrazine oxidoreductase gene abundance.
\end{abstract}

Keywords Anammox $\cdot$ Immobilization $\cdot$ Polyvinyl alcohol $\cdot$ Relative gene abundance $\cdot$ Sodium alginate

\section{Introduction}

For decades, biological anaerobic ammonium oxidation (anammox) has been considered as a promising and costeffective process for nitrogen removal from wastewater. Anammox targets wastewater that contains high concentrations of ammonium, such as landfill leachate and digester effluents. The process application could lead to reduction in operational costs of up to $90 \%$. In comparison with traditional denitrification-nitrification methods, the process

Editorial responsibility: Fatih Şen.

Date and location of the research carried out throughout the study Research were carried out in Environmental Biotechnology Department, Silesian University of Technology, Poland in 2019.

A. Banach-Wiśniewska

anna.banach-wisniewska@polsl.pl

1 Environmental Biotechnology Department, Faculty of Power and Environmental Engineering, Silesian University of Technology, Akademicka 2, 44-100 Gliwice, Poland does not require an external carbon source and allows the reduction in aeration costs. Moreover, anammox application has been linked to reduced greenhouse gas emissions (for instance $\mathrm{N}_{2} \mathrm{O}$ ) (Ma et al. 2016; Cao et al. 2017). However, despite obvious advantages, the application of anammox is limited due to the low growth rate of anammox bacteria, and the sensitivity of this process to changes in environmental conditions (Zhang et al. 2017). In technical systems, the optimal temperature for anammox bacteria is $30^{\circ} \mathrm{C} \pm 5{ }^{\circ} \mathrm{C}$, which is higher than the average temperature of sewage entering the wastewater treatment plant $\left(15^{\circ} \mathrm{C} \pm 3{ }^{\circ} \mathrm{C}\right)$. Implementation of anammox below its optimal temperature called cold anammox, and without decreasing its efficiency may lead to the more widespread use of this process in the main stream of the wastewater treatment plant and, consequently, in the reduction in operational costs (Tomaszewski et al. 2017; Wu et al. 2018). Under unfavorable conditions, anammox biomass growth is often inhibited, while fastgrowing heterotrophs start to dominate. Thus, an additional challenge for anammox application is to enable bacterial cell retention in the reactor (Winkler et al. 2018; Li et al. 2018). The promising approach to cultivate slow-growing bacteria 
and to develop a stable and high-rate nitrogen removal anammox system is the immobilization of anammox sludge in gel carriers, using natural and synthetic biomaterials (Martins et al. 2013). In comparison with conventional systems with suspended biomass, entrapping biomass in carriers could facilitate bacterial growth, promote biomass retention in the reactors. Moreover, it could protect the biomass from changes in environmental parameters, such as temperature changes. However, the selection of suitable immobilization material is crucial. Among materials suited for activated sludge immobilization, synthetic polymers, such as polyvinyl alcohol (PVA), present advantages in the wastewater treatment field (Tan et al. 2018; Guerrero et al. 2012). They are non-toxic for bacteria, mechanically resistant, and capable of enhancing process efficiency (Magrí et al. 2012). Among the natural polymers applied in cell immobilization, alginates are the most commonly used ones (Goh et al. 2012). Sodium alginate (SA) as a natural polymer has been widely investigated in the context of activated sludge immobilization (Ali et al. 2015; Dong et al. 2017). The entrapment procedure is easy and not related to significant changes in the physicochemical conditions for immobilized microorganisms. Both SA and PVA, as well as their combination, provide favorable conditions for immobilized microorganisms and effective exchange of substances with the environment (Mirzaie et al. 2019). Several studies have shown that alginate addition to PVA allowed to improve the network structure of PVA hydrogel carriers and reduced their mass transfer resistance (Kaur et al. 2019). PVA-SA was used as a matrix to immobilize anammox and nitrifying bacteria by Qiao et al. (2013) and Bae et al. (2015). The authors of a previous study obtained total nitrogen removal efficiencies of 77 and $88.9 \%$, respectively. Similarly, Chen et al. (2015a, b) mentioned PVA-SA as a suitable material for anammox bacteria immobilization.

Against the background of the limitations and advantages of immobilization on SA and PVA, the aim of this study was to support cold anammox by entrapping anammox sludge in PVA-SA gel beads. The protective properties of anammox sludge immobilization may open a way to a wider application of anammox process in the main stream of the treatment in wastewater treatment plants, and may enhance the anammox sludge retention in the operational systems. Several studies have focused on whole cell anammox or enrichment anammox cultures entrapped in gel carriers (for example, Quan et al. 2011; Zhu et al. 2014). However, in technological systems, anammox performed by activated sludge often involves a heterogeneous microbial consortium, including other nitrogen-removing bacterial groups. The relations between the various bacterial groups and the fate of anammox bacteria entrapped in gel carriers are still not well understood. Thus, we compared the effect of immobilization on anammox performed during temperature shifts with the relative gene abundance estimated for the key functional nitrogen removal bacterial groups. The relative gene abundance was estimated for the most common nitrogenremoving bacterial groups in activated sludge: anammox bacteria, ammonia-oxidizing bacteria (AOB), nitriteoxidizing bacteria (NOB), and denitrifiers.

\section{Materials and methods}

\section{Biomass characteristics}

Anammox sludge used for immobilization was taken from laboratory-scale anammox sequencing batch reactors (SBRs) with a volume of $5 \mathrm{~L}$, which had been operated stably for 6 months. Reactor operated at temperature $30 \pm 2{ }^{\circ} \mathrm{C}$ and $\mathrm{pH} 7.5 \pm 3$. The SBRs were previously inoculated with anammox from a full-scale deamonification SBR in Germany. The anammox sludge had a granular structure, with reddish granules measuring 1-3 mm; DNA sequencing revealed that the dominant anammox genera were $\mathrm{Ca}$. $\mathrm{Bro}$ cadia accounted for $30.57 \%$ and Ca. Scalindua accounted for $3.95 \%$. Prior to immobilization, the anammox biomass was washed thrice with phosphate buffer saline $(0.01 \mathrm{M}$, $\mathrm{pH}=7.4$ ) to remove residual substrate from the sludge surface.

\section{Fluorescent in situ hybridization}

Fluorescently labeled oligonucleotide probes AMX 368 and a mix of oligonucleotides EUB-338, EUB-338 II, and EUB-338 III were used for the rapid evaluation of anammox bacteria in the gel carriers. Single PVA-SA gel beads were treated with ethylenediaminetetraacetic acid to release immobilized bacteria, and subsequently, the anammox sludge was spotted onto Teflon-coated multiwell slides. The FISH procedure was conducted as it was described previously by Ziembińska-Buczyńska et al. (2019).

\section{Carrier preparation and characteristics}

\section{Immobilization procedure}

For the long-term experiment, alginate water solution containing $7 \%$ PVA (w/v; Sigma-Aldrich) and 2\% SA (w/v; SigmaAldrich) was prepared by vigorously mixing and heating with a temperature gradient from 23 to $70{ }^{\circ} \mathrm{C}$, until dissolved. After cooling down to room temperature, anammox biomass was added to PVA/SA solution at a ratio of $1: 1$ and stirred together. The stirring mixture was dropped by peristaltic pump to the cross-linking solution contained $50 \% \mathrm{w} / \mathrm{v} \mathrm{NaNO}_{3}$ and $2 \% \mathrm{w} / \mathrm{v} \mathrm{CaCl}_{2}$. The beads were immersed in cross-linking 
solution for $0.5 \mathrm{~h}$, then immediately rinsed several times with large amounts of distilled water to stop the immobilization and to remove extra alginate or PVA from the bead surface (Banach et al. 2018).

\section{Calculation of sphericity factor of the gel beads}

The obtained pellets were not perfectly spherical in shape, making it necessary to calculate a sphericity factor (SF). The diameters of the single pellets were measured and the values were used to determine SF, using Eq. 1:

$\mathrm{SF}=\frac{d_{\max }-d_{\text {min }}}{d_{\max }+d_{\min }}$

where $d_{\max }$ is the maximum pellet diameter and $d_{\min }$ is the minimum pellet diameter.

\section{Measurement of absorption capacity of methylene blue by the gel beads}

To estimate the absorption capacity, the gel beads were prepared with different polyvinyl alcohol concentrations (2\% sodium alginate $-2.5 \%$ polyvinyl alcohol, $2 \%$ sodium alginate-5\% polyvinyl alcohol, 2\% SA-10\% PVA, and 2\% SA-15\% PVA). The beads were incubated at alkaline, neutral, and acidic conditions at 15,23 , and $30^{\circ} \mathrm{C}$. Prepared pellets were weighed and placed in $50 \mathrm{~mL}$ of $20 \mathrm{mg} \mathrm{L}^{-1}$ methylene blue (MB) solution. Subsequently, the changes in absorbance over time were measured, allowing us to estimate the absorption capacity coefficient and the MB removal rate. The supernatant was taken to determine absorbance, using a UV-Vis spectrophotometer at $665 \mathrm{~nm}$. The absorption capacity coefficient $\left(q_{\mathrm{MB}}\right)$ and the removal rate $\left(R_{\mathrm{MB}}\right)(\mathrm{Wu}$ et al. 2017) were calculated using Eqs. 2 and 3, respectively:

$R_{\mathrm{MB}}=\frac{C_{0}-C_{\mathrm{e}}}{C_{0}} * 100 \%$

$q_{\mathrm{MB}}=\frac{\left(C_{0}-C_{\mathrm{e}}\right) * V}{m} * 100 \%$

where $C_{0}$ is the initial MB concentration $\left(\mathrm{mg} \mathrm{L}^{-1}\right), C_{\mathrm{e}}$ is the equilibrium concentration of $\mathrm{MB}\left(\mathrm{mg} \mathrm{L}^{-1}\right), V$ is the volume of MB solution, and $m$ is the pellet mass.

\section{Preparation of the samples for the scanning electron microscopy}

The application of scanning electron microscopy (SEM, QUANTA FEG 250, Thermo Fisher) allowed us to determine and characterize pellet morphology and structure. First, the beads were washed with phosphate buffer saline solution with $\mathrm{pH}=7.4$ and then dried at room temperature in a silica gel dryer. Subsequently, the samples were vacuumdried and sputtered with gold.

\section{Measurements of physicochemical parameters in SBR reactors}

Levels of $\mathrm{N}-\mathrm{NH}_{4}, \mathrm{~N}-\mathrm{NO}_{2}$, and $\mathrm{N}-\mathrm{NO}_{3}$ were measured regularly with fast photometric tests (MERCK Millipore) using a photometer (MERCK Spectroquant ${ }^{\circledR}$ NOVA60). The $\mathrm{pH}$ and temperature were monitored using a JUMO tecLine HD- $\mathrm{pH}$ combination electrode. Dissolved oxygen concentration was measured via an ELMETRON conductivity/oxygen meter CCO-505 equipped with an ELMETRON COG-1 oxygen sensor. The concentrations of Volatile Suspended Solids were determined according to the standard method (APHA 2005).

\section{Short-term effects of temperature and immobilization on specific anammox activity- batch experiments}

The short-term effect of gel entrapment was investigated via series of batch experiments and specific anammox activity (SAA) evaluation. Each batch experiment was performed at least in triplicate. Tests were conducted for $12 \mathrm{~h}$ at $15^{\circ} \mathrm{C}$ and $30{ }^{\circ} \mathrm{C}$ with a pH value of 7.5. During the tests, samples for nitrogen concentration measurements were collected at 30-min intervals. The specific anammox activity (SAA) was measured by calculating the linear descending slopes of $\mathrm{N}-\mathrm{NH}_{4}$ and $\mathrm{N}-\mathrm{NO}_{2}$ concentrations. To calculate the SAA, the removal rates for $\mathrm{N}-\mathrm{NH}_{4}$ and $\mathrm{N}-\mathrm{NO}_{2}$ were normalized by volatile suspended solids.

\section{Long-term effects of temperature and immobilization on nitrogen removal and bacterial gene abundance-experimental setup}

The experiment lasted for 91 days and was conducted in two SBRs with a volume of $5 \mathrm{~L}$; the temperature was changed from $30{ }^{\circ} \mathrm{C}$ (days 1 to 30 of the experiment) through $23^{\circ} \mathrm{C}$ (days 35 to 60 of the experiment) to $15^{\circ} \mathrm{C}$ (days 69 to 91 of the experiment). Between each stage of the experiment, the temperature was gradually decreasing by $1-2{ }^{\circ} \mathrm{C}$ per day. The first reactor was used as a control and inoculated with non-immobilized anammox sludge, while the second reactor was inoculated with anammox biomass entrapped in PVA-SA gel beads. Initial biomass concentration in the control reactor was $1.22 \mathrm{gVSSL}^{-1}$, while in the PVA-SA reactor, it was $1.15 \mathrm{gVSS} \mathrm{L}^{-1}$. During the experiment, the reactors were operated at a $\mathrm{pH}$ level of $7.6 \pm 0.4$, which was corrected using $10 \% \mathrm{HCl}$ and $10 \% \mathrm{NaOH}$. Dissolved 
oxygen (DO) concentration was below $0.1 \mathrm{mg} \mathrm{L}^{-1}$, and hydraulic retention time (HRT) was $1 \mathrm{~d}$. The SBRs were fed with mineral medium containing: $0.048 \mathrm{~g} \mathrm{KHCO}_{3}$ $\mathrm{L}^{-1}, 0.041 \mathrm{~g} \mathrm{KH}_{2} \mathrm{PO}_{4} \mathrm{~L}^{-1}, 0.228 \mathrm{~g} \mathrm{MgSO}_{4} 7 \mathrm{H}_{2} \mathrm{O} \mathrm{L}{ }^{-1}$, and $0.007 \mathrm{~g} \mathrm{FeSO}_{4} 7 \mathrm{H}_{2} \mathrm{O} \mathrm{L}^{-1}$. The nitrogen concentration was regulated using $\mathrm{NH}_{4} \mathrm{Cl} \mathrm{L}^{-1}$ and $\mathrm{NaNO}_{2} \mathrm{~L}^{-1}$ and was approximately $100 \mathrm{mg} \mathrm{N} \mathrm{L}^{-1}$, which is close in value to the nitrogen concentration in the main stream of the wastewater treatment plant.

\section{Sampling procedure and DNA isolation from anammox biomass}

Samples were collected from inoculum and from SBRs on days 14, 40, 61, 70, and 91 of the experiment and were protected with RNA-Later (Promega) to avoid genetic material degradation. Prior to the isolation procedure, samples were washed thrice to remove potential PCR inhibitors and then stored at $-40{ }^{\circ} \mathrm{C}$ until DNA isolation. The DNA was isolated as described previously (ZiembińskaBuczyńska et al. 2019). Isolated DNA was treated with the Anty-inhibitor Kit (A\&A Biotechnology) according to the manufacturer instruction.

\section{Quantitative polymerase chain reaction}

The Quantitative Polymerase Chain Reaction (qPCR) analysis was performed to measure the abundance of functional genes specific for particular nitrogen-removing bacterial groups. Relative gene abundance was calculated at the beginning and at the end of each temperature phase of the experiment. Primer sequences with specificity and target genes are summarized in Table 1. The qPCR procedure has been described in details in the previous study by Ziembińska-Buczyńska et al. (2019). All reactions were conducted at least in triplicate; Eq. 4 was used to calculate relative gene abundance $(q)$ :
$q=2^{\Delta C_{t}}$

where $\Delta c_{t}=C_{t r e f}-C_{\text {tanal }} ; C_{\text {tref }}$ is the $C_{t}$ of the bacterial $16 \mathrm{~S}$ rRNA coding gene (used as a reference gene).

\section{Statistical analysis}

The significance level $\alpha=0.05$ was adopted for all performed statistical analyses. Data normality was tested with the Shapiro-Wilk test, and Leven's test was performed to test the equality of variances. Two-way analysis of variance (ANOVA) was used to examine the significance of the differences between SAA calculated under different experimental conditions and nitrogen removal performance. The temperature and the immobilization occurrence were considered as a factors affecting the dependent variable. In addition, Spearman's rank correlation coefficients were calculated between physiochemical parameters of the process and relative genes abundance. All of the tests were conducted in MS Excel 2013 and STATISTICA 13.1 Software.

\section{Results and discussion}

\section{Carrier characteristics}

The anammox sludge was successfully immobilized in PVASA gel beads (Fig. 1a). The FISH results confirmed anammox bacteria presence in the carriers (Fig. 1b). The surface of the SA-PVA gel beads was finely porous, which facilitates nitrogen diffusion. Some buckling and some conglomeration could be observed, suggesting good compatibility between SA-PVA and anammox biomass, which results in a uniform distribution in the SA-PVA matrix (Fig. 1c, d).

The PVA intermolecular interact with alginate through hydrogen bonding (Aadil et al. 2018). The obtained gel

Table 1 Primers used for qPCR

\begin{tabular}{|c|c|c|c|c|}
\hline Primers & Specificity & Target gene & Encoding enzyme & Sequence $5^{\prime}-3^{\prime}$ \\
\hline $1055 \mathrm{~F}$ & Bacteria & 16S rRNA & Universal bacterial marker gene & ATGGCTGTCGTCAGCT \\
\hline $1392 \mathrm{R}$ & & & & ACGGGCGGTGTGTAC \\
\hline amoA-1-F & Ammonia oxidizers & Amo & Ammonia monooxygenase & GGGGTTTCTACTGGTGGT \\
\hline amoA-2R & & & & CCCCTCKGSAAAGCCTTCTTC \\
\hline nxrA-RT-F & Nitrite oxidizers & $N r x$ & Nitrite oxidoreductase & GTG GTC ATG CGC GTT GAG CA \\
\hline nxrA-RT-R & & & & TCG GGA GCG CCA TCA TCC AT \\
\hline hzoCl1f1 & All known Planctomycetes & $\mathrm{Hzo}$ & Hydrazine oxidoreductase & TGYAAGACYTGYCAYTGG \\
\hline hzoCl1r2 & & & & ACTCCAGATRTGCTGACC \\
\hline $\operatorname{nirS} 1 \mathrm{f}$ & Denitrifiers & $\mathrm{NirS}$ & Nitrite reductase & TACCACCCSGARCCGCGCGT \\
\hline $\operatorname{nirS} 3 r$ & & & & GCCGCCGTCRTGVAGGAA \\
\hline nirK876 & & NirK & & ATYGGCGGVCAYGGCGA \\
\hline nirK1040 & & & & GCCTCGATCAGRTTRTGGTT \\
\hline
\end{tabular}


Fig. 1 SA-PVA carriers; a with immobilized anammox biomass; b FISH image of anammox bacteria from gel beads under a confocal microscope, amx368-labeled with Cy3 red, EUBmix - labeled with FLUOS-green; $\mathbf{c}$ surface of SA-PVA bead; $\mathbf{d}$ and single gel bead with immobilized anammox sludge under a scanning electron microscope

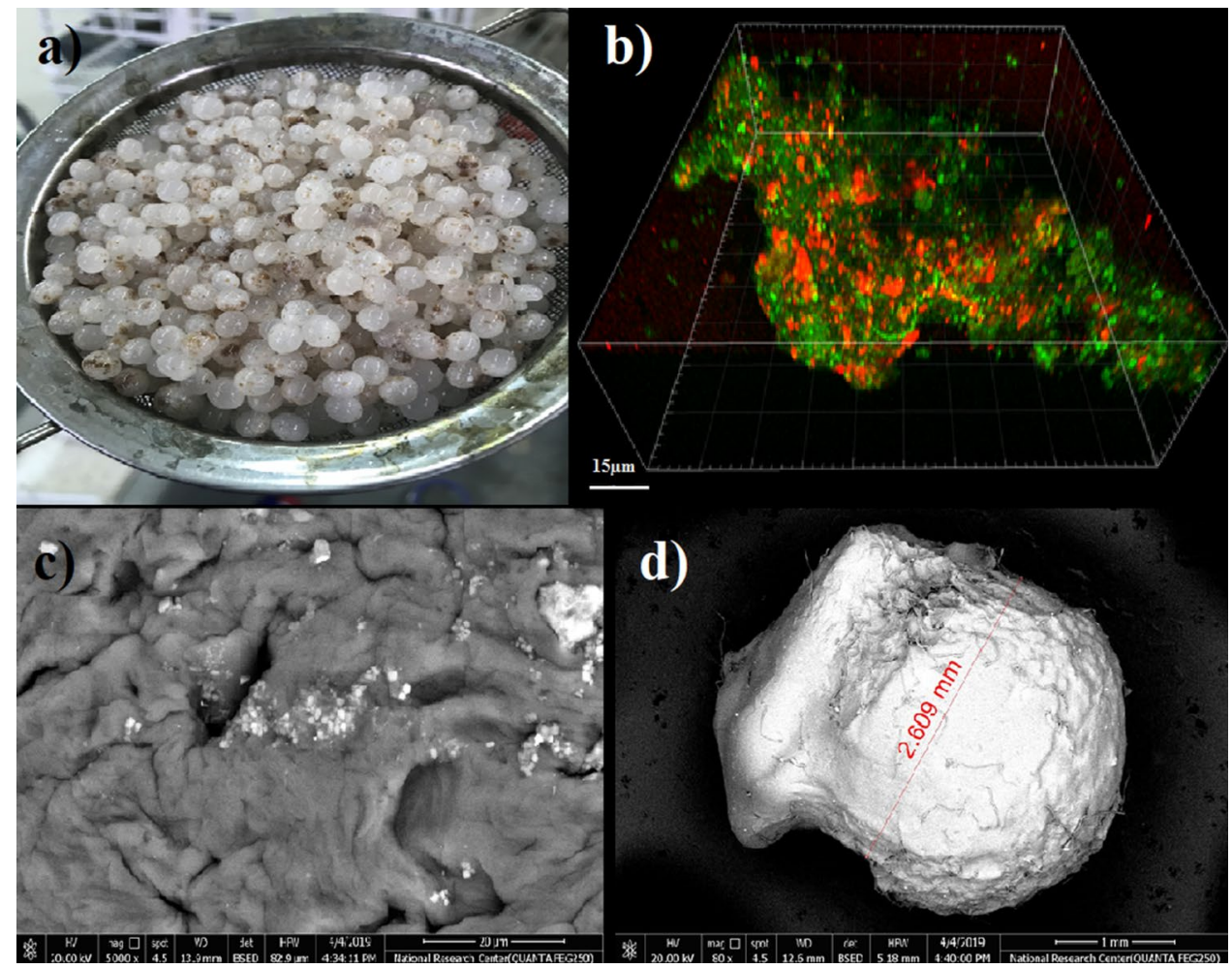

beads presented the combined advantages of both PVA and SA. PVA alone is characterized by good mechanical properties, while SA is characterized by high hydrophilicity, because of its $-\mathrm{COOH}$ and $-\mathrm{OH}$ groups, which take part in hydrogen bonding and van der Waals forces. In addition, the presence of sodium ions from SA improved the elasticity of the PVA-SA gel beads (Mohammed et al. 2016; Kaur et al. 2019). In our study, the diameter of the gel beads at the swelling equilibrium state was, on average, $4.6 \pm 0.42 \mathrm{~mm}$. As the obtained gel beads showed not model, but similar spherical shapes, the sphericity coefficient (SF) was calculated as $0.092 \pm 0.03$. Granules are considered as spherical when the sphericity coefficient is below 0.05 . An SF of up to 0.1 indicates elongated beads (Voo et al. 2016). Most of the obtained gel beads were close to the elongated shape, which might have been caused by the distance of the condensation channel to the cross-linking agent solution surface during the immobilization procedure.

The absorption abilities of the carriers are significant properties for wastewater treatment and are directly connected with nutrient diffusion and process efficiency. The methylene blue absorption capacity test allowed to estimate the absorption abilities of the gel beads as depending on $\mathrm{pH}$, temperature, and PVA concentration. The PVASA beads are characterized by a high number of hydroxyl groups, and therefore, adsorption of the MB dye by gel beads is affected by electrostatic interactions and hydrogen bonds between negatively charged granules and positively charged methylene blue (Wang et al. 2018). Mohammed et al. (2016) also observed that great absorption of MB is caused because of osmotic swelling. Concentration inside of pellets characterizes itself as smaller than outside of them, what caused the diffusion of the MB into the hydrogel beads. Comparing the granules incubated at different $\mathrm{pH}$ levels, the highest absorption coefficient was obtained at $23{ }^{\circ} \mathrm{C}$ under alkaline conditions, and alkaline conditions were the most favorable ones for MB absorption. Similar observations have been made by Wang et al. (2018) in an experiment where, after gel bead incubation in a strongly alkaline environment, hydroxyl groups were deprotonated, resulting in an increased negative charge on the surface of the PVA-SA. A greater negative charge in an alkaline environment, compared to neutral conditions, caused an improvement in the already effective absorption of the dye by the PVA-SA beads. In this studies, $\mathrm{pH}$ had a significant impact on the MB absorption coefficient, and differences in the dependence on $\mathrm{pH}$ were noticed at the end of the experiment (Fig. 2). Temperature also had a significant effect on absorption. Li et al. (2017) report that increased temperatures decreased the absorption capacity, but the authors only tested absorption on sodium alginate. In the case of our studies, among the tested temperatures, the highest values were obtained for $23{ }^{\circ} \mathrm{C}$ and $15{ }^{\circ} \mathrm{C}$ (Tables 2, 3, and 4). Differences among the investigated temperatures were statistically significant. 
Fig. 2 PVA-SA gel beads after $\mathrm{MB}$ absorption under alkaline (a) and acidic (b) conditions
Table 2 Methylene blue absorption coefficient $\left(q_{\mathrm{MB}}\right)$ calculated for PVA-SA gel beads in neutral $\mathrm{pH}$ at $15^{\circ} \mathrm{C}$, $23{ }^{\circ} \mathrm{C}$, and $30^{\circ} \mathrm{C}$
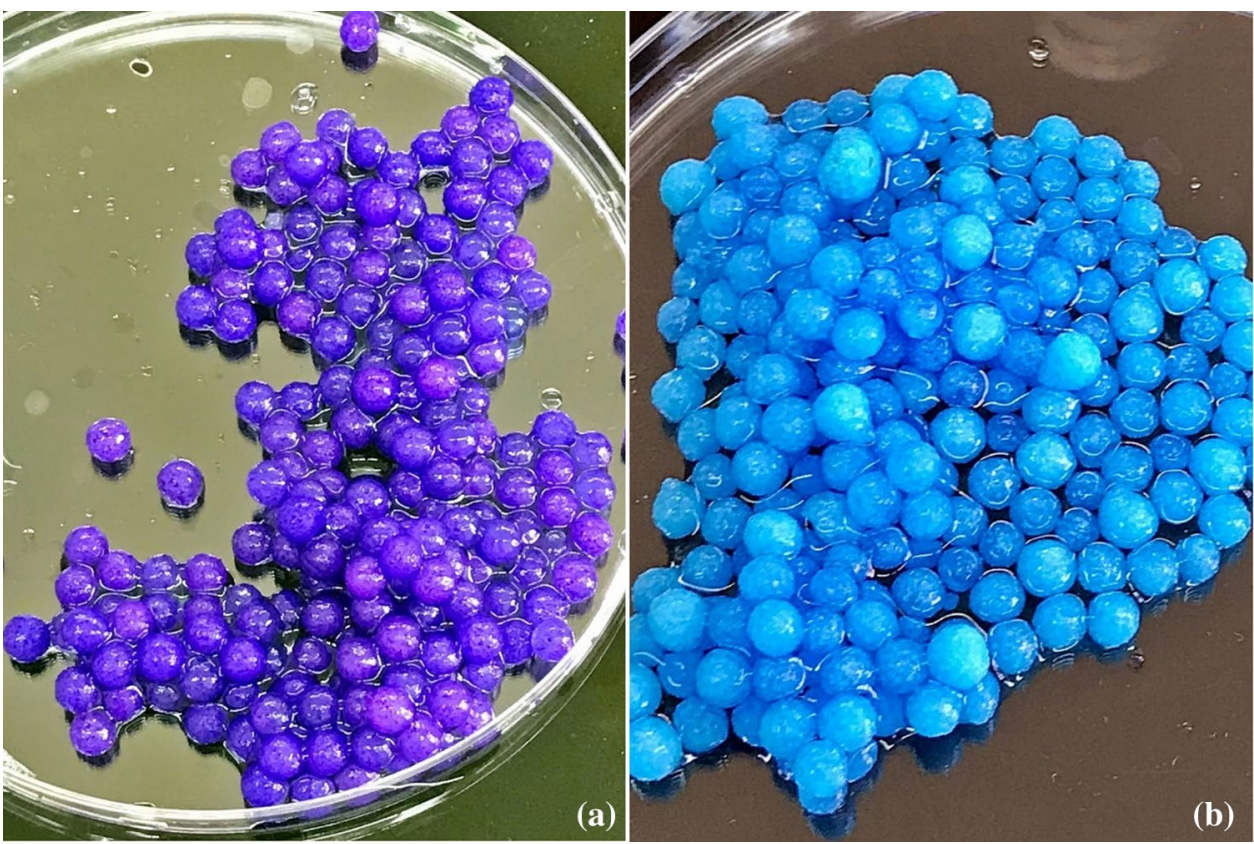

\begin{tabular}{lllll}
\hline $\begin{array}{l}\text { Temperature } \\
\left({ }^{\circ} \mathrm{C}\right)\end{array}$ & PVA concentration & & & \\
\cline { 2 - 5 } & 2\% SA-2.5\% PVA & 2\% SA-5\% PVA & 2\% SA-10\% PVA & 2\% SA-15\% PVA \\
\hline 15 & 0.1023 & 0.1995 & 0.1678 & 0.1761 \\
23 & 0.2066 & 0.2146 & 0.0917 & 1.1732 \\
30 & 0.6225 & 0.2641 & 0.5339 & 0.7639 \\
\hline
\end{tabular}

Data represent means of at least three replications

\begin{tabular}{lllll}
\hline $\begin{array}{l}\text { Temperature } \\
\left({ }^{\circ} \mathrm{C}\right)\end{array}$ & PVA concentration & & & \\
\cline { 2 - 5 } & 2\% SA-2.5\% PVA & 2\% SA-5\% PVA & 2\% SA-10\% PVA & 2\% SA-15\% PVA \\
\hline 15 & 0.9047 & 0.473 & 1.5532 & 0.6411 \\
23 & 0.2066 & 0.2145 & 0.0917 & 1.1732 \\
30 & 0.6225 & 0.2641 & 0.5339 & 0.7639 \\
\hline
\end{tabular}

Data represent means of at least three replications

Table 4 Methylene blue absorption coefficient $\left(q_{\mathrm{MB}}\right)$ calculated for PVA-SA gel beads in acidic $\mathrm{pH}$ at $15^{\circ} \mathrm{C}$, $23{ }^{\circ} \mathrm{C}$, and $30^{\circ} \mathrm{C}$

\begin{tabular}{lllll}
\hline $\begin{array}{l}\text { Temperature } \\
\left({ }^{\circ} \mathrm{C}\right)\end{array}$ & PVA concentration & & & \\
\cline { 2 - 5 } & 2\% SA-2.5\% PVA & 2\% SA-5\% PVA & 2\% SA-10\% PVA & 2\% SA-15\% PVA \\
\hline 15 & 0.0909 & 0.0588 & 0.1574 & 0.1100 \\
23 & 0.1468 & 0.1551 & 0.3082 & 0.1912 \\
30 & 0.0775 & 0.0635 & 0.0542 & 0.0592 \\
\hline
\end{tabular}

Data represent means of at least three replications

\section{Short- and long-term effects of temperature and immobilization on anammox performance}

Since bacteria are capable to adapt well to environmental changes during long-term cultivation, the influence of particular parameters should be verified via long- and shortterm experiments (Canion et al. 2014; Tomaszewski et al. 2017). Based on carrier properties and available literature, PVA-SA carriers with 7\% PVA and 2\% SA concentrations were chosen for the studies of nitrogen removal efficiency 
(Ali et al. 2015; Chen et al. 2015a, b; Dong et al. 2017). The short-term effects of immobilization and temperature on anammox performance were evaluated via the specific anammox activity calculated during the batch experiments (Table 5).

Both for anammox biomass entrapped in the SA-PVA carriers and for suspended anammox biomass, a decrease in

Table 5 Specific anammox activity (SAA) calculated at $15{ }^{\circ} \mathrm{C}, 23{ }^{\circ} \mathrm{C}$, and $30{ }^{\circ} \mathrm{C}$ for immobilized anammox biomass and control (nonimmobilized anammox biomass)

\begin{tabular}{lll}
\hline SAA $\left[\mathrm{gN}^{\mathrm{gVVSS}}{ }^{-1} \cdot \mathrm{d}^{-1}\right]$ & \\
\hline & Control & Immobilized biomass \\
\hline $30^{\circ} \mathrm{C}$ & $0.206 \pm 0.015$ & $0.175 \pm 0.01$ \\
$15^{\circ} \mathrm{C}$ & $0.12 \pm 0.03$ & $0.138 \pm 0.01$ \\
$p$-values (two- & For temperature & $<\mathbf{0 . 0 1}$ \\
way ANOVA) & For the immobilization & 0.575 \\
& Combined for & $\mathbf{0 . 0 4 8}$ \\
& immobilization and & \\
& temperature & \\
\hline
\end{tabular}

Data represent means and standard deviation

Bold values indicate statistically significance $p<0.05$
SAA at $15{ }^{\circ} \mathrm{C}$ was noticed, and temperature had a statistically significant effect on SAA. A less significant difference between SAA, calculated at $30{ }^{\circ} \mathrm{C}$ and $15^{\circ} \mathrm{C}$, was observed in the case of biomass immobilized in SA-PVA carriers in comparison with suspended biomass. Combination of temperature changes and immobilization had a significant effect on the calculated SAA $(p=0.048)$. However, the $p$ value calculated for only immobilization was above the assumed level of significance. The slower diffusion of products and substrates from immobilized biomass to the environment and the resistance to mass transfer may help us to understate the results in the short-term experiments. Dosta et al. (2008) pointed out that a higher specific anammox activity may be achieved by the gradual adaptation of the biomass to the low temperatures. Thus, further investigations of the PVA-SA effect on nitrogen removal were performed during the long-term experiment.

Two anammox SBRs, control (non-immobilized biomass) and PVA-SA (immobilized biomass), were investigated for 91 days with a temperature shift from $30^{\circ} \mathrm{C}$ through $23^{\circ} \mathrm{C}$ to $15{ }^{\circ} \mathrm{C}$. The physicochemical results (Figs. 3 and 4) were summarized with nitrogen-removing bacterial groups, calculated as relative functional gene abundance (Fig. 5).
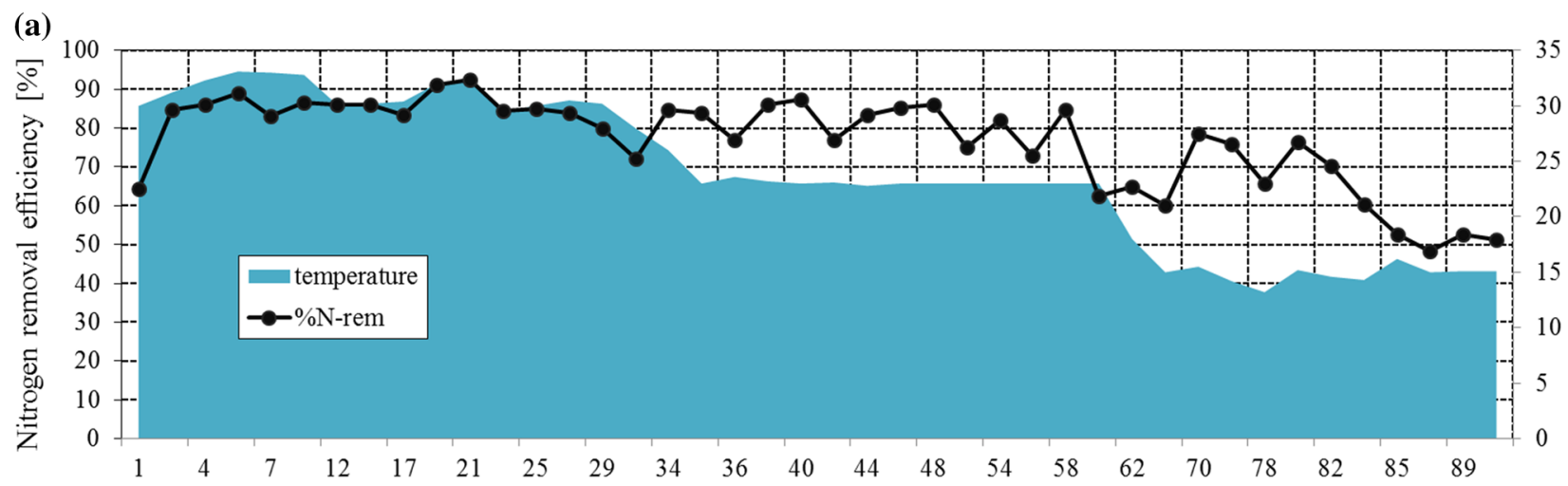

(b)

Time [days]

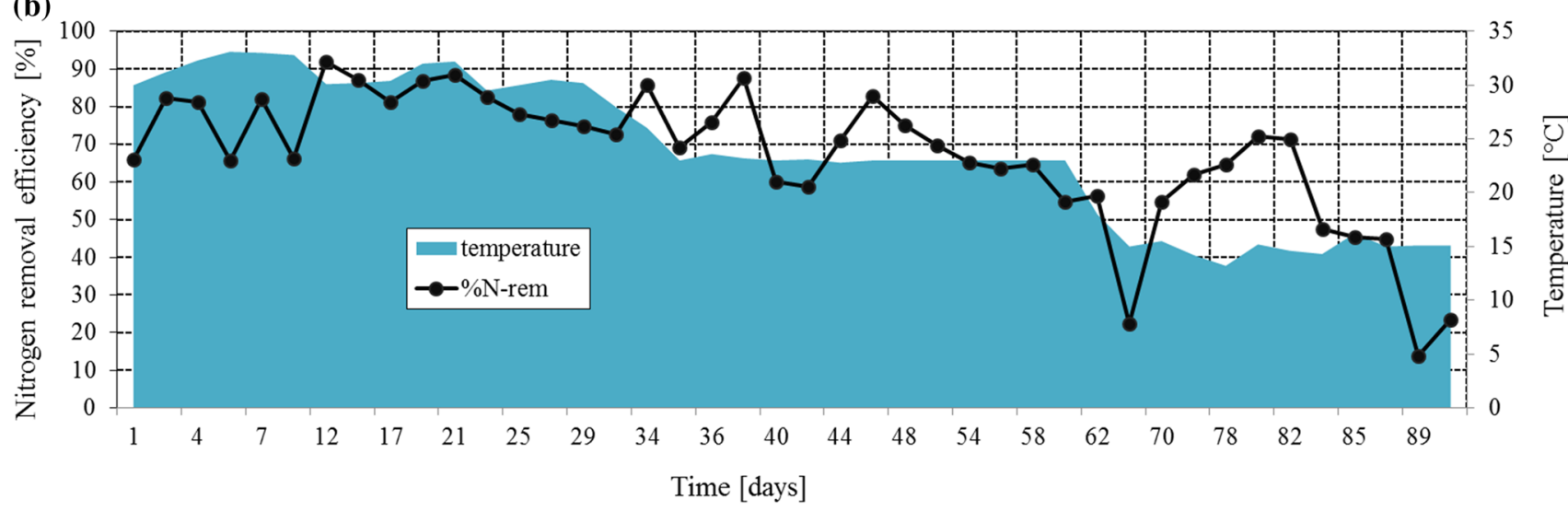

Fig. 3 Total nitrogen removal efficiency (\%N-rem) calculated for the PVA-SA SBR reactor (a) and control SBR reactor (b) during temperature shift from $30{ }^{\circ} \mathrm{C}$ through $23{ }^{\circ} \mathrm{C}$ to $15^{\circ} \mathrm{C}$ 

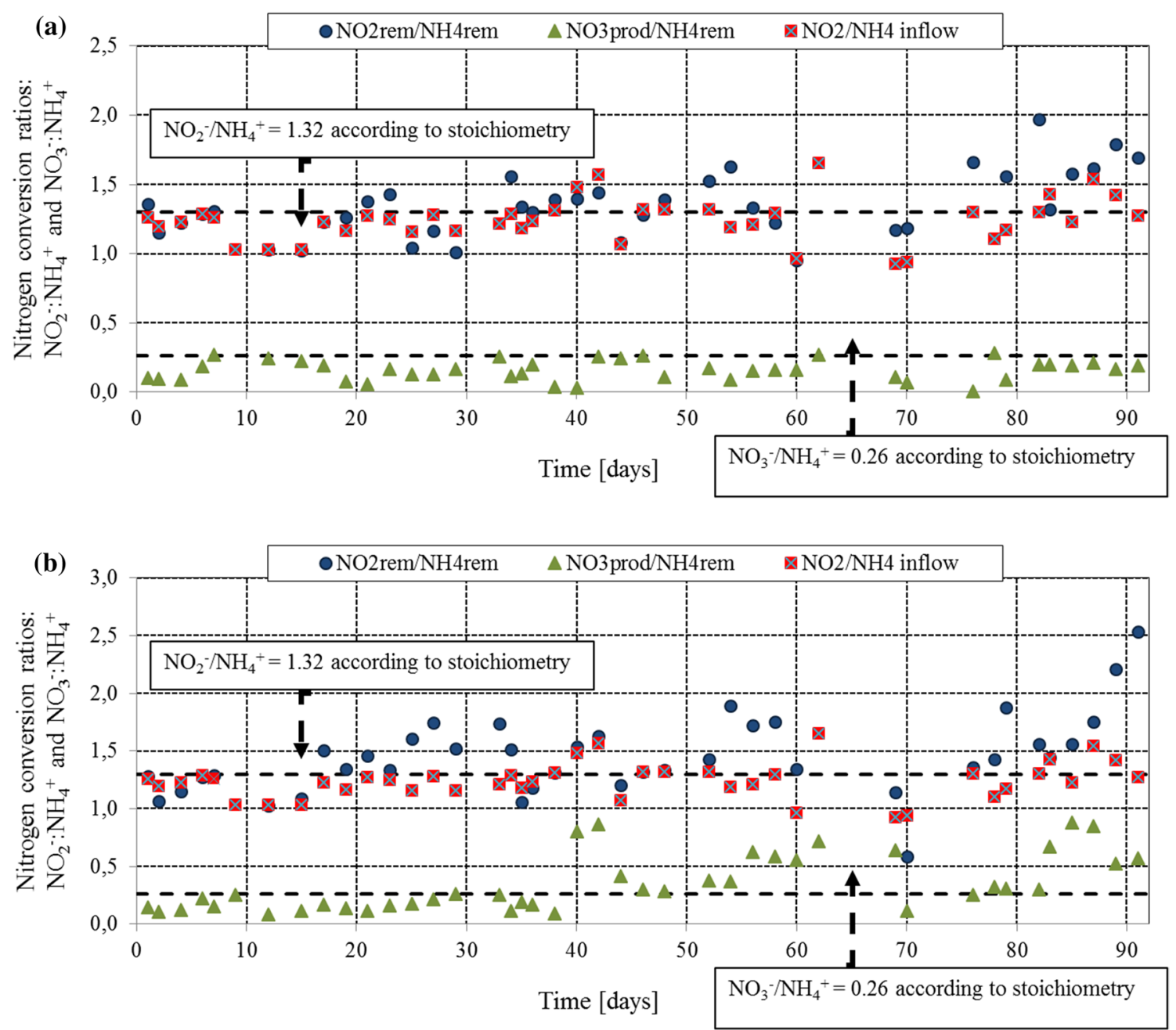

Fig. $4 \mathrm{NO}_{2}{ }^{-}$removed: $\mathrm{NH}_{4}{ }^{+}$removed and $\mathrm{NO}_{3}{ }^{-}$produced: $\mathrm{NH}_{4}{ }^{+}$ removed ratios calculated for the PVA-SA SBR reactor (a) and control SBR reactor (b) during temperature shift from $30{ }^{\circ} \mathrm{C}$ through
$23{ }^{\circ} \mathrm{C}$ to $15{ }^{\circ} \mathrm{C}$. Horizontal lines indicate values of 0.26 and 1.32 , according to the most popular anammox reaction stoichiometry (Banach-Wiśniewska et al. 2020)
The anammox sludge exhibited high nitrogen removal efficiency (NRE) at $30{ }^{\circ} \mathrm{C}: 83.7 \pm 6.46 \%$ in the PVA-SA reactor and $79.4 \pm 7.83 \%$ in the control reactor. In the control reactor, two decreases in NRE were noticed during the experimental phase at $15{ }^{\circ} \mathrm{C}$ : at day 69 from 56.4 to $22.4 \%$ and at day 89 from 44.9 to $13.8 \%$. Successful performance of the anammox process at $16^{\circ} \mathrm{C}$ was achieved by Ma et al. (2016), but anammox activity rapidly decreased below $15{ }^{\circ} \mathrm{C}$. In our studies, in both SBRs, after a temperature shift from 23 to $15{ }^{\circ} \mathrm{C}$, nitrogen removal efficiency was temporarily restored to levels above $70 \%$, and NRE in the PVA-SA reactor achieved $78.4 \%$ on day 70 , immediately after a temperature decrease to $15{ }^{\circ} \mathrm{C}$. In the case of immobilization, NRE did not decrease drastically in the last phase of the experiment. At the end of the experiment in days 84-91, the NRE for the PVA-SA reactor remained at the level of $50 \pm 2.5 \%$, while for the control reactor, it fluctuated from 13.2 to $45.3 \%$. Both temperature and immobilization effects on nitrogen removal efficiency were statistically significant (Table 6).

Anammox performed by biomass immobilized in PVASA gel carriers was more stable in comparison with nonimmobilized biomass, which was reflected both in the NRE and in the calculated molar ratios for particular nitrogen compounds (Fig. 4). Similarly, Lu et al. (2018) report that a reactor inoculated with biomass immobilized in PVA-SA was more stable regarding nitrogen removal. In this study, up to day 70 of the experiment, the ratios of the $\mathrm{NO}_{2}{ }^{-}$to $\mathrm{NH}^{+}$ removed were close to 1.32 , and the ratio of $\mathrm{NO}_{3}{ }^{-}$produced to $\mathrm{NH}_{4}{ }^{+}$was close to 0.26 in the PVA-SA reactor, which are the theoretical values for anammox, and indicates that anammox was responsible for nitrogen removal in the reactor (Magrí et al. 2012). It should be also noted that the $h z o$ gene was the most abundant gene among the nitrogen-removing 

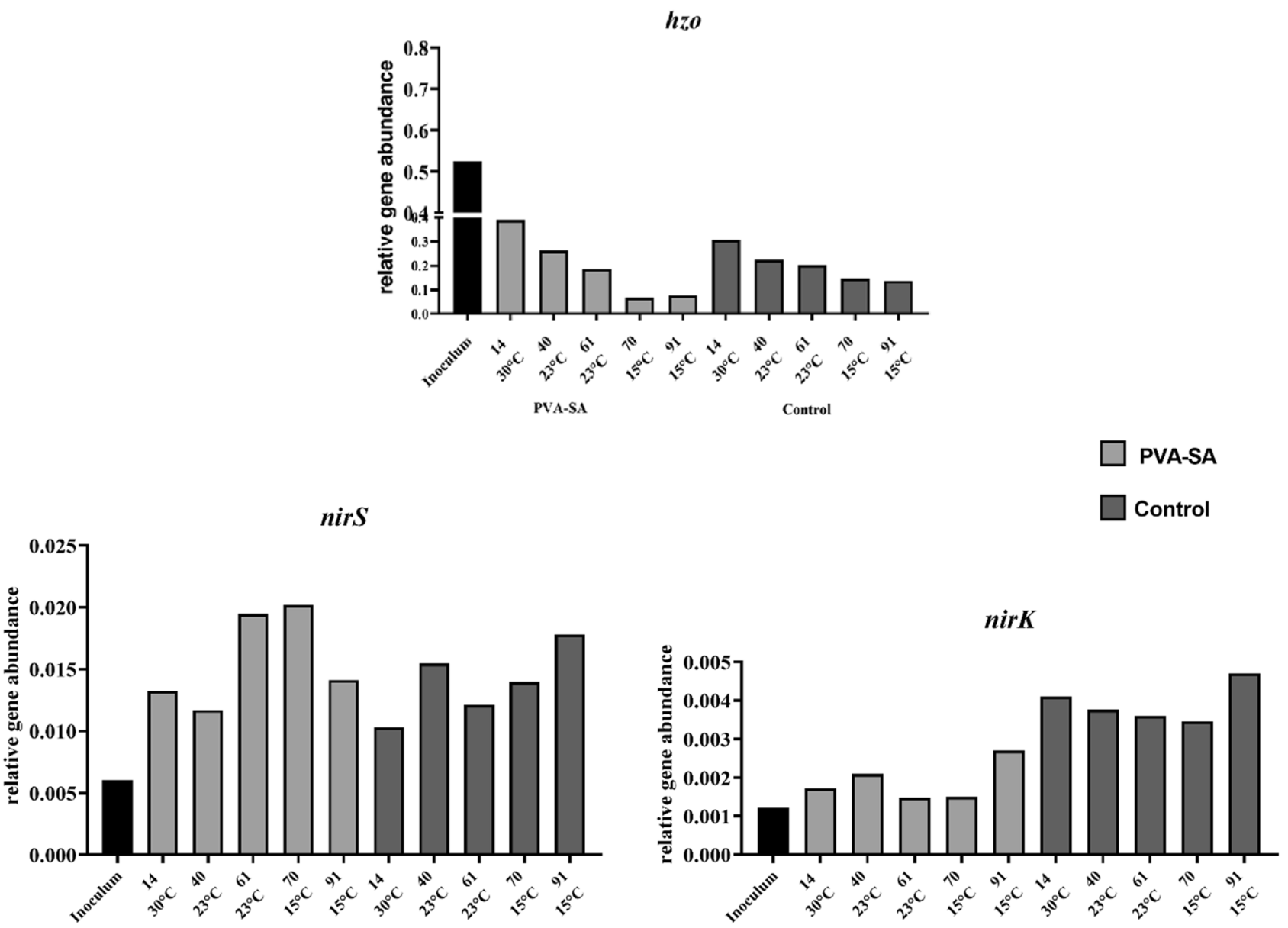

$\operatorname{amoA}$
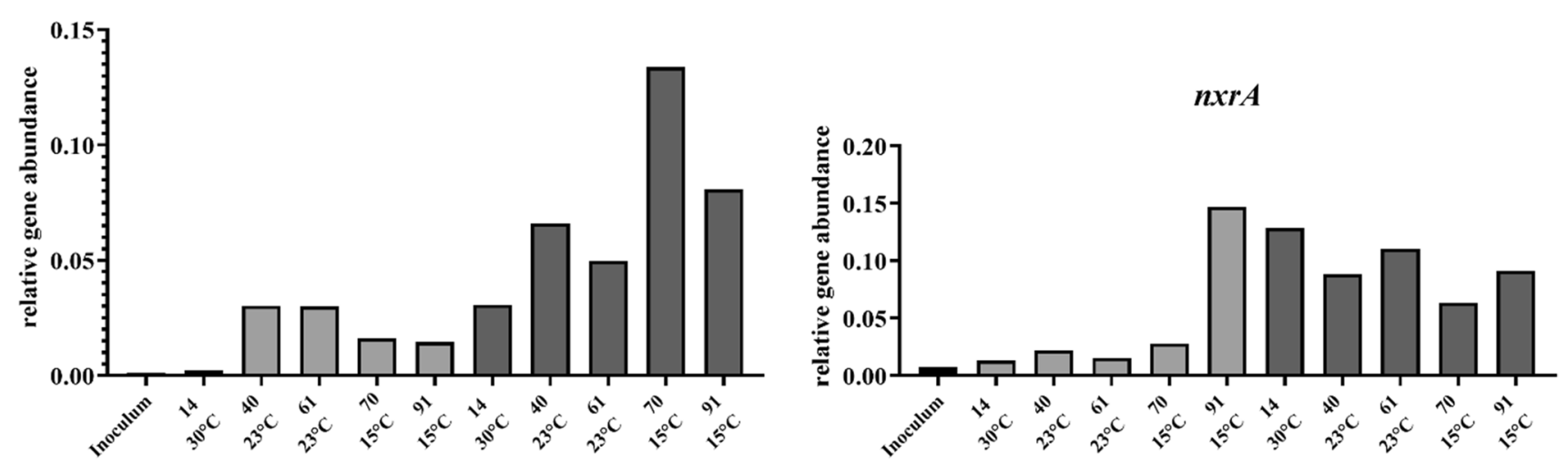

Fig. 5 Relative abundances of $h z o, n x r A$, amoA, nirK, and nirS genes calculated for biomass in the control reactor and biomass immobilized in polyvinyl alcohol-sodium alginate beads. Samples were taken on days 14, 40, 61, 70, and 91 of the experiment

bacterial genes investigated in the anammox biomass (Fig. 5). Moreover, a statistically significant correlation was found between nitrogen removal efficiency and hzo gene abundance, specifically for anammox bacteria $(0.685$, $p=0.0289$ ), while no statistically significant correlation was found between physicochemical parameters and relative gene abundancy calculated for the remaining investigated nitrogen-removing bacterial groups (Table 7). The stoichiometric anammox activity was successfully retained in PVASA gel carriers. However, after day 76 of the experiment, the $\mathrm{NO}_{2}^{-}$to $\mathrm{NH}_{4}{ }^{+}$removal ratio exceeded 1.32 and hesitated from 1.96 to 2.93 , indicating nitrification contribution in 
Table 6 Results of two-way ANOVA for nitrogen removal rates in investigated SBRs; Factor 1-immobilization, Factor 2-temperature; SSsum of squares; $\mathrm{df}$ —degrees of freedom; MS - mean square; $F$ - variance ratio; $p$ - probability; $\eta^{2}$ —mean-squared error

\begin{tabular}{|c|c|c|c|c|c|c|}
\hline & SS & df & MS & $F$ & $p$ & $\eta^{2}$ \\
\hline Immobilization & 1834.749 & 1 & 1834.749 & 15.880 & $<0.001$ & 0.166 \\
\hline Temperature & 9649.978 & 2 & 4824.989 & 41.762 & $<0.001$ & 0.511 \\
\hline Immobilization*Temperature & 485.125 & 2 & 242.563 & 2.099 & 0.129 & 0.050 \\
\hline Error & 9242.834 & 80 & 115.535 & & & \\
\hline In total & $21,212.686$ & 85 & & & & \\
\hline
\end{tabular}

Bold values indicate statistically significance $p<0.05$

Table 7 Spearman rank coefficient calculated between nirS, nirK, amoA, nxrA, and $h z o$ relative gene abundances and nitrogen removal efficiency (NRE)

\begin{tabular}{|c|c|c|c|c|c|c|}
\hline & $n i r S$ & nirK & amoA & $n x r A$ & hzo & NRE \\
\hline nirs & 1.000 & & & & & \\
\hline nirK & -0.333 & 1.000 & & & & \\
\hline amoA & -0.067 & 0.697 & 1.000 & & & \\
\hline$n x r A$ & -0.224 & 0.697 & 0.297 & 1.000 & & \\
\hline hzo & -0.721 & 0.115 & -0.079 & -0.273 & 1.000 & \\
\hline$N R E$ & -0.370 & -0.467 & -0.527 & -0.600 & 0.685 & 1.000 \\
\hline
\end{tabular}

Bold values indicate statistically significance $p<0.05$ nitrogen transformation. At the same time, the abundance of the nxrA gene, characteristic for NOB microorganisms, increased drastically in the sample taken from the PVA-SA reactor at day 91 of the experiment (Fig. 5). It is worth to mention that nxrA gene used for NOB monitoring is among others, characteristic for Nitrospira which possesses the metabolic potential to perform the complete oxidation of ammonia to nitrate (comammox) (Pinto et al. 2015). Along with the nitrification, the comammox process may contribute in nitrogen removal in investigated reactors.

In the control reactor, calculated molar ratios were characteristic for the nitrification: the ratios were higher than 1.32 and 0.26 for the $\mathrm{NO}_{2}{ }^{-}$removed: $\mathrm{NH}_{4}{ }^{+}$removed and $\mathrm{NO}_{3}{ }^{-}$produced: $\mathrm{NH}_{4}{ }^{+}$removed, respectively. Moreover, the relative abundance of amoA gene increased in the samples from days 70 to 91. In Dosta et al. (2008), a temperature decrease to $15{ }^{\circ} \mathrm{C}$ caused nitrite accumulation and loss of process stability. In our studies, in the control reactor, nitrogen removal was less stable after the first temperature decrease (from 30 to $23{ }^{\circ} \mathrm{C}$ ), and nitrification contribution was noticed from day 40 of the experiment, which was reflected in the molar ratio increase. Nitrification contribution and increase in nitrifier-related functional genes in the control SBR were probably connected with the environmental preferences of NOB and AOB. Nitrifying bacteria prefer temperatures similar to those in sewage treatment plants (Wang et al. 2016). In the PVA-SA reactor, in comparison with the control, we noticed a less significant decrease in NRE, molar ratios closer for anammox process stoichiometry, and no significant increase in amoA and $n x r A$ gene abundance immediately after temperature decrease, suggesting that immobilization in PVA-SA facilitates temperature shock resistance during long-term operation and protects the immobilized biomass during temperature changes.

In both reactors, denitrifying bacterial gene abundance was lower when compared to AOB, NOB, and anammoxrelated genes. This suggests that denitrifiers were present in activated sludge, but were less active because of the specific conditions. The reactors were fed with organic compound-free medium, while organic carbon is needed for the development of denitrifiers. However, a slight increase in relative gene abundance during the experiment and a drop in $\mathrm{NO}_{3}{ }^{-}$produced: $\mathrm{NH}_{4}{ }^{+}$removed ratios suggest a slight role of denitrification in nitrogen removal, as the denitrifiers may start to use inactive parts of biomass or immobilization reagents as organic carbon source (in example SA) (Figs. 4 and 5).

Technology may promote the growth of one group of bacteria (anammox), but the results of the qPCR clearly show that the remaining bacteria are present in such reactors, albeit in a considerably smaller proportion.

\section{Conclusion}

The qPCR results and the FISH images confirmed that anammox bacteria coexist with other bacterial groups in the gel carriers. The abundance of hzo gene decreased with decreasing temperature, and hzo gene abundance was correlated with nitrogen removal efficiency. A slower decrease in nitrogen removal efficiency during temperature changes in the case of immobilized biomass suggests that 
immobilization in PVA-SA is temperature shock-resistant during long-term operation. Nitrogen removal efficiency in the PVA-SA reactor achieved $78.4 \%$, immediately after a temperature decrease to $15{ }^{\circ} \mathrm{C}$. Moreover, the nitrogen removal was more stable in PVA-SA reactor, what may indicate protective properties of immobilization for investigated biomass. Such properties of anammox sludge immobilization may open a way to a wider application of anammox process in the main stream of the treatment in wastewater treatment plants.

Acknowledgments The authors would like to thank Mateusz Kuc for help with nitrogen concentration measurements and Mohammed Saad Hellal and the National Research Centre in Cairo for help with scanning electron microscopy images.

Funding This research was financed by the Polish National Science Center under the Grant 2016/23/N/NZ9/02147.

\section{Compliance with ethical standards}

Conflict of interest No potential conflict of interest was reported by the authors.

Ethical approval This article does not contain any studies with human participants or animals performed by any of the authors.

Open Access This article is licensed under a Creative Commons Attribution 4.0 International License, which permits use, sharing, adaptation, distribution and reproduction in any medium or format, as long as you give appropriate credit to the original author(s) and the source, provide a link to the Creative Commons licence, and indicate if changes were made. The images or other third party material in this article are included in the article's Creative Commons licence, unless indicated otherwise in a credit line to the material. If material is not included in the article's Creative Commons licence and your intended use is not permitted by statutory regulation or exceeds the permitted use, you will need to obtain permission directly from the copyright holder. To view a copy of this licence, visit http://creativecommons .org/licenses/by/4.0/.

\section{References}

Aadil KR, Nathani A, Sharma CS, Lenka N, Gupta P (2018) Fabrication of biocompatible alginate-poly (vinyl alcohol) nanofibers scaffolds for tissue engineering applications. Mater Technol 33(8):507-512

Ali M, Oshiki M, Rathnayake L, Ishii S, Satoh H, Okabe S (2015) Rapid and successful start-up of anammox process by immobilizing the minimal quantity of biomass in PVA-SA gel beads. Water Res 79:147-157

APHA (2005) Standard methods for the examination of water and wastewater, twentieth ed. American Water Works Association (AWWA) and Wat Env Fed (WEF), Washington (DC)

Bae H, Choi M, Lee C, Chung YC, Yoo YJ, Lee S (2015) Enrichment of ANAMMOX bacteria from conventional activated sludge entrapped in poly (vinyl alcohol)/sodium alginate gel. Chem Eng J 281:531-540
Banach A, Pudlo A, Ziembińska-Buczyńska A (2018) Immobilization of anammox biomass in sodium alginate. In: E3S web of conferences, vol 44, p 00008. EDP Sciences

Banach-Wiśniewska A, Tomaszewski M, Cema G, ZiembińskaBuczyńska A (2020) Medium shift influence on nitrogen removal bacteria: ecophysiology and anammox process performance. Chemosphere 238:124597

Canion A, Kostka JE, Gihring TM, Huettel M, Van Beusekom JEE, Gao H, Kuypers MM (2014) Temperature response of denitrification and anammox reveals the adaptation of microbial communities to in situ temperatures in permeable marine sediments that span 50 in latitude. Biogeosciences 11(2):309-320

Cao Y, van Loosdrecht MC, Daigger GT (2017) Mainstream partial nitritation-anammox in municipal wastewater treatment: status, bottlenecks, and further studies. Appl Microbiol Biotechnol 101(4):1365-1383

Chen G, Li J, Tabassum S, Zhang Z (2015a) Anaerobic ammonium oxidation (ANAMMOX) sludge immobilized by waterborne polyurethane and its nitrogen removal performance-a lab scale study. RSC Adv 5(32):25372-25381

Chen G, Li J, Deng H, Dong Q, Zhang Y, Zheng Z, Hou A (2015b) Study on anaerobic ammoniumoxidation (ANAMMOX) sludge immobilized in different gel carriers and its nitrogen removal performance. J Resid Sci Technol 12:S47-S54

Dong Y, Zhang Y, Tu B (2017) Immobilization of ammonia-oxidizing bacteria by polyvinyl alcohol and sodium alginate. Braz $\mathrm{J}$ Microbiol 48(3):515-521

Dosta J, Fernández I, Vázquez-Padín JR, Mosquera-Corral A, Campos JL, Mata-Alvarez J, Méndez R (2008) Short-and long-term effects of temperature on the anammox process. J Hazard Mater 154(1-3):688-693

Goh CH, Heng PWS, Chan LW (2012) Alginates as a useful natural polymer for microencapsulation and therapeutic applications. Carbohydr Polym 88(1):1-12

Guerrero JA, Almeida-Naranjo CE, Villamar Ayala CA (2012) Improvement of nutrients removal from domestic wastewater by activated-sludge encapsulation with polyvinyl alcohol (PVA). J Environ Sci Health, Part A 54(8):721-727

Kaur P, Gondil VS, Chhibber S (2019) A novel wound dressing consisting of PVA-SA hybrid hydrogel membrane for topical delivery of bacteriophages and antibiotics. Int J Pharm 572:118779

Li Q, Li Y, Ma X, Du Q, Sui K, Wang D, Wang C, Li H, Xia Y (2017) Filtration and adsorption properties of porous calcium alginate membrane for methylene blue removal from water. Chem Eng J 316:623-630

Li J, Li J, Gao R, Wang M, Yang L, Wang X, Zhang L, Peng Y (2018) A critical review of one-stage anammox processes for treating industrial wastewater: optimization strategies based on key functional microorganisms. Bioresour Technol 265:498-505

Lu Y, Ma L, Liang Y, Shan B, Chang J (2018) Enhancing nitrogen removal performance in a bioreactor using immobilized anaerobic ammonium oxidation sludge by polyvinyl alcohol-sodium alginate (PVA-SA). Pol J Environ Stud 27(2):773-778

Ma B, Wang S, Cao S, Miao Y, Jia F, Du R, Peng Y (2016) Biological nitrogen removal from sewage via anammox: recent advances. Bioresour Technol 200:981-990

Magrí A, Vanotti MB, Szögi AA (2012) Anammox sludge immobilized in polyvinyl alcohol (PVA) cryogel carriers. Bioresour Technol 114:231-240

Martins SCS, Martins CM, Fiúza LMCG, Santaella ST (2013) Immobilization of microbial cells: a promising tool for treatment of toxic pollutants in industrial wastewater. Afr J Biotechnol 12(28):4412-4418

Mirzaie Z, Reisi-Vanani A, Barati M (2019) Polyvinyl alcoholsodium alginate blend, composited with $3 \mathrm{D}$-graphene oxide 
as a controlled release system for curcumin. J Drug Deliv Sci Technol 50:380-387

Mohammed N, Grishkewich N, Waeijen HA, Berry RM, Tam KC (2016) Continuous flow adsorption of methylene blue by cellulose nanocrystal-alginate hydrogel beads in fixed bed columns. Carbohydr Polym 136:1194-1202

Pinto AJ, Marcus DN, Ijaz UZ, Bautista-de Lose Santos QM, Dick GJ, Raskin L (2015) Metagenomic evidence for the presence of comammox nitrospira-like bacteria in a drinking water system. mSphere 30(1):e00015-e00054

Qiao S, Tian T, Duan X, Zhou J, Cheng Y (2013) Novel single-stage autotrophic nitrogen removal via co-immobilizing partial nitrifying and anammox biomass. Chem Eng J 230:19-26

Quan LM, Hira D, Fujii T, Furukawa K (2011) Reject water treatment by improvement of whole cell anammox entrapment using polyvinyl alcohol/alginate gel. Biodegradation 22(6):1155-1167

Tan BY, Chu ZR, Wu GR, Luo HY, Rong HW (2018) Preparation and properties of PVA-SA hydrogel biocarrier. J Guangzhou Univ Natural Sci Ed 2:14

Tomaszewski M, Cema G, Ziembińska-Buczyńska A (2017) Influence of temperature and $\mathrm{pH}$ on the anammox process: a review and meta-analysis. Chemosphere 182:203-214

Voo WP, Ooi C-W, Islam A, Tey B-T, Chan E-S (2016) Calcium alginate hydrogel beads with high stiffness and extended dissolution behavior. Eur Polym J 75:343-353

Wang Y, Fang H, Zhou D, Han H, Chen J (2016) Characterization of nitrous oxide and nitric oxide emissions from a full-scale biological aerated filter for secondary nitrification. Chem Eng J 299:304-313

Wang W, Zhao Y, Bai H, Zhang T, Ibarra-Galvan V, Song S (2018) Methylene blue removal from water using the hydrogel beads of poly(vinyl alcohol)-sodium alginate-chitosan-montmorillonite carbohydrate. Polymers 198:518-528

Winkler MKH, Meunier C, Henriet O, Mahillon J, Suárez-Ojeda ME, Del Moro G, Weissbrodt DG (2018) An integrative review of granular sludge for the biological removal of nutrients and recalcitrant organic matter from wastewater. Chem Eng J 336:489-502

Wu Y, Qi H, Shi C, Ma R, Liu S, Huang Z (2017) Preparation and adsorption behaviors of sodium alginate-based adsorbentimmobilized $\beta$-cyclodextrin and graphene oxid. RSC Adv 7(50):31549-31557

Wu P, Chen Y, Ji X, Liu W, Lv G, Shen Y, Zhou Q (2018) Fast startup of the cold-anammox process with different inoculums at low temperature $\left(13^{\circ} \mathrm{C}\right)$ in innovative reactor. Bioresour Technol 267:696-703

Zhang L, Narita Y, Gao L, Ali M, Oshiki M, Ishii S, Okabe S (2017) Microbial competition among anammox bacteria in nitrite-limited bioreactors. Water Res 125:249-258

Zhu GL, Yan J, Hu YY (2014) Anaerobic ammonium oxidation in polyvinyl alcohol and sodium alginate immobilized biomass system: a potential tool to maintain anammox biomass in application. Water Sci Technol 69(4):718-726

Ziembińska-Buczyńska A, Banach-Wiśniewska A, Tomaszewski M, Poprawa I, Student S, Cema G (2019) Ecophysiology and dynamics of nitrogen removal bacteria in a sequencing batch reactor during wastewater treatment start-up. Int J Environ Sci Technol 16(8):4215-4222 